\title{
Targeting PPAR $\alpha$ for the Treatment and Understanding of Cardiovascular Diseases
}

\author{
Shuzhen Lia,b,c Bingyu Yang ${ }^{a, b, c}$ Yang Du ${ }^{a, b, c}$ Yurui Lin ${ }^{a, b, c}$ Jiaqi Liu ${ }^{a, b, c}$ \\ Songming Huang ${ }^{a, b, c}$ Aihua Zhang ${ }^{a, b, c}$ Zhanjun Jia ${ }^{a, b, c}$ Yue Zhang ${ }^{a, b, c}$ \\ aDepartment of Nephrology, Children's Hospital of Nanjing Medical University, Nanjing, bJiangsu Key \\ Laboratory of Pediatrics, Nanjing Medical University, Nanjing, cNanjing Key Laboratory of Pediatrics, \\ Children's Hospital of Nanjing Medical University, Nanjing, China
}

\author{
Key Words \\ $\operatorname{PPAR} \alpha \cdot$ Vascular injury $\bullet$ Cardiac injury $\bullet$ Blood pressure $\bullet$ Lipid disorder
}

\begin{abstract}
Three members of the peroxisome proliferator-activated receptor (PPAR) family, PPAR $\alpha$, PPAR $\gamma$, and PPAR $\beta / \delta$, have been investigated widely over the past few decades. Although the roles of these PPARs and their agonists/antagonists were defined in clinical and basic studies, the conflicting results from these studies indicate that more analysis is needed to understand the roles of PPARs. PPAR $\alpha$ is a ligand-activated transcription factor that contributes to the regulation of a variety of processes, ranging from inflammation and immunity to nutrient metabolism and energy homeostasis. In this review, we focus on the function and mechanisms of PPAR $\alpha$ in the cardiovascular system under various pathological conditions, including vascular and heart injury, blood pressure regulation, and lipid disorder-related cardiovascular injury, as well as its polymorphisms and pharmacogenetic associations with cardiovascular diseases. The anti-inflammatory effect of PPAR $\alpha$ in cardiovascular injury is mainly through inhibition of pro-inflammatory signaling pathways and improvement of the lipid profile. Moreover, PPAR $\alpha$ also modulates the activity of endothelial nitric oxide synthase and resets the renin-angiotensin system to regulate vascular tone. PPAR $\alpha$ gene variants appear to be associated with some cardiovascular risk factors, such as higher plasma lipid levels, cardiac growth, and increased risk of coronary artery disease. Nowadays, novel PPAR $\alpha$ drugs with broad safety margins and therapeutic potential for metabolic syndrome and cardiovascular diseases are being developed and applied in the clinical setting. The insights from the current review shed new light on areas of further study and provide a better understanding of the role of PPAR $\alpha$ in cardiovascular diseases.




\section{Cellular Physiology Cell Physiol Biochem 2018;51:2760-2775 \\ and Biochemistry Published \begin{tabular}{l|l} 
DOI: $10.1159 / 000495969$ & (c) 2018 The Author(s). Published by S. Karger AG, Basel \\
www.karger.com/cpb
\end{tabular} \\ Li et al.: PPAR $\alpha$ in Cardiovascular Diseases}

\section{Introduction}

After a mouse gene linked to peroxisome proliferation was first described in 1990 [1], an orphan nuclear hormone receptor named peroxisome proliferator-activated receptor (PPAR) was subsequently discovered. The original receptor, known as PPAR $\alpha$ (also termed NR1C), was classified as a PPAR forming group C in subfamily 1 of the nuclear hormone receptor superfamily. cDNAs encoding two other isotypes of this nuclear receptor subfamily, PPAR $\beta / \delta$ (NR1C2) and PPAR $\gamma$ (NR1C3), were then identified. All three PPARs are encoded by separate genes and expressed in amphibians [2], rodents [3, 4], and humans [5, 6]. PPAR $\alpha$ and PPAR $\gamma$ appear to be highly conserved across species, whereas PPAR $\beta / \delta$ has diverged considerably [4].

PPAR $\alpha$ is expressed in skeletal muscle, liver, intestine, kidney, and heart [7, 8], with different patterns of protein and mRNA expression in mice, rats, and humans [9]. In the cardiovascular system, the activation of PPAR $\alpha$ by its ligands inhibits the development and progression of atherosclerosis, plaque rupture, and thrombus formation [10, 11]. In this review, we focus on the advances in our understanding of the roles of PPAR $\alpha$ in cardiovascular disorders, namely, vascular injury, heart diseases, lipid disorders, and hypertension.

\section{General characteristics and roles of PPAR $\alpha$, PPARY, and PPAR $\beta / \delta$}

All members of this PPAR superfamily have a similar structure. The N-terminal region allows ligand-independent activation, confers constitutive activity on the receptor, and is negatively regulated by phosphorylation. This region is followed by a DNA-binding domain (two zinc finger motifs separated by a linker region) and a C-terminal ligand-binding domain $[12,13]$. The three members of the PPAR family are encoded by separate genes with distinct but overlapping interspecies sequences and exert distinct functions [14]. PPARs form heterodimers with another nuclear receptor partner, retinoid X receptor, and bind to specific PPAR response elements in the promoter region of their target genes, thereby regulating gene function (Fig. 1). PPARs can also repress gene expression in a DNA binding-independent manner by interfering with other signaling pathways [15].

PPAR $\alpha$, the first identified PPAR, is expressed abundantly in skeletal muscle, liver, intestine, kidney, and heart $[9,16]$, and regulates fatty acid (FA) transport, esterification, and oxidation $[17,18]$. Moreover, it also plays a critical role in inhibiting cell proliferation and tumorigenesis via unidentified mechanisms. PPAR $\gamma$ is the best studied PPAR subtype and is expressed predominantly in brown and white adipose tissues and to a lesser extent in immune cells and the intestinal mucosa [19]. PPAR $\beta / \delta$ is expressed at high levels in most tissues, but especially in skeletal muscle, liver, intestine, kidney, and abdominal adipose tissue. Its activation results in increased FA oxidation (FAO) in skeletal and cardiac muscle and improves insulin sensitivity in insulin-resistant animal models [20,21].

PPARs are involved in multiple physiological functions [22] that are regulated by a large number of endogenous and exogenous compounds, including FAs and their metabolites. A variety of ligands, including n-3 and n-6 FAs, eicosanoids, and a few endocannabinoids and phospholipids, have been identified as endogenous ligands of PPARs, including 8-epoxyeicosatrienoic acids (8-EETs), the arachidonic acid lipoxygenase metabolite leukotriene B4 (LTB4), and the arachidonate monooxygenase metabolites epoxyeicosatrienoic acids, which have been shown to potently activate PPAR $\alpha$ [2325]. Besides these endogenous PPAR ligands, some exogenous PPAR ligands have been generated and applied in experimental studies and clinical practice. For example, fibrates, which are PPAR $\alpha$ ligands, are used widely to ameliorate the microvascular risks associated with metabolic syndrome [26]. This class of exogenous PPAR $\alpha$ ligands includes clofibrate, gemfibrozil, fenofibrate, bezafibrate, and ciprofibrate [27-32]. Furthermore, the synthetic compounds GW501516, GW0742, L-165041, and GW2433 have been defined as selective $\operatorname{PPAR} \beta / \delta$ ligands $[33,34]$. Natural PPAR $\gamma$ ligands include 15-deoxy-(12, 14)-prostaglandin 


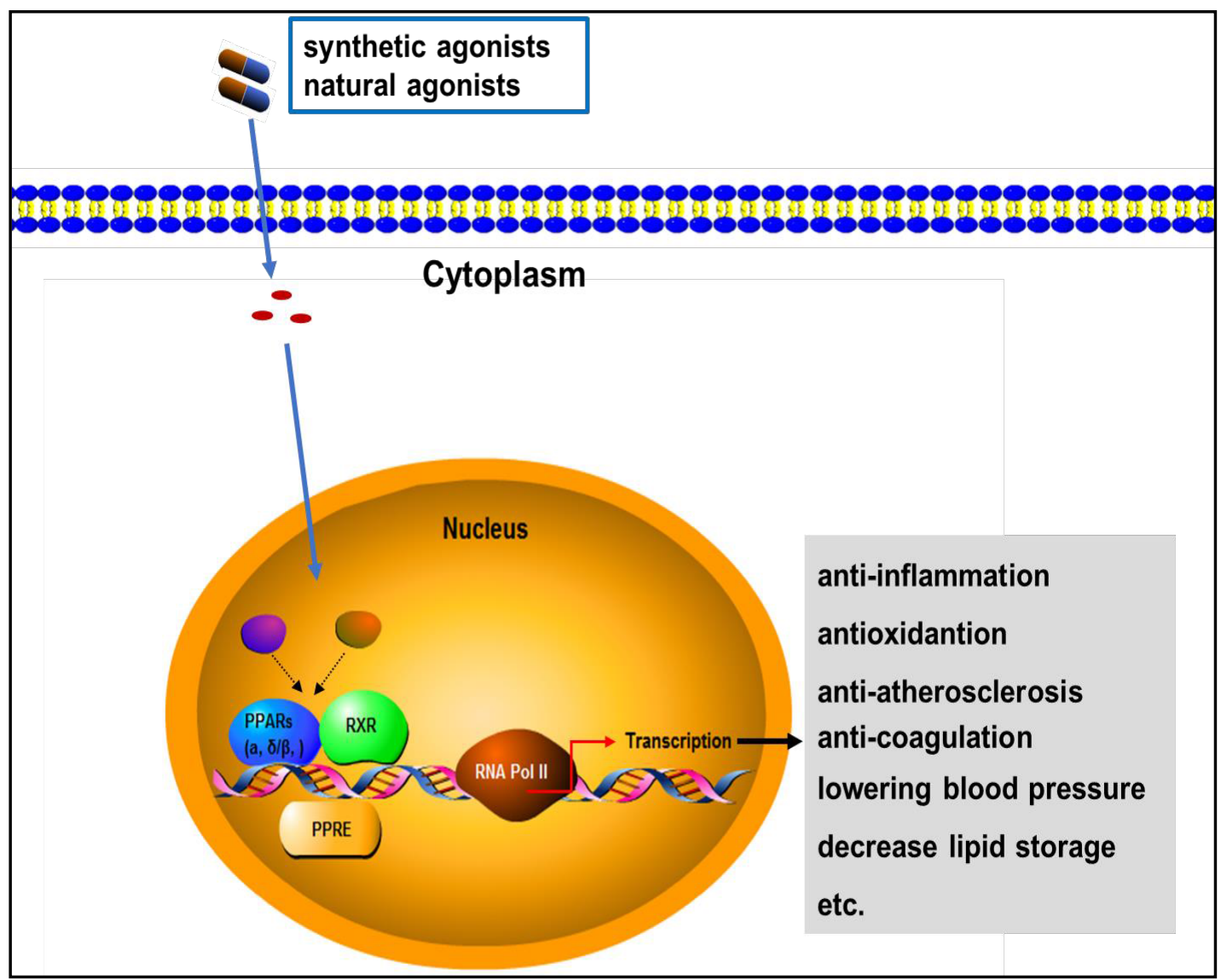

Fig. 1. Schematic of peroxisome proliferator-activated receptors-(PPARs) in cardiovascular diseases. PPARs have three forms: $\alpha, \beta / \delta$, and $\gamma$. PPAR heterodimerizes with retinoid X receptor- (RXR) and binds to the specific region of DNA sequence known as the peroxisome proliferator receptor response element (PPRE) located in the promoters of PPAR target genes, which leads to initiation of transcription by recruiting RNA polymerase II (RNA Pol II) and other transcription factors. In pathological conditions, PPARs protect against the vascular injury through multiple actions.

J2 [35] and the oxidized metabolites of linoleic acid 9-hydroxy- and 13-hydroxyoctadecadienoic acids [36, 37]. Synthetic thiazolidinedione (TZD) compounds, including rosiglitazone, pioglitazone, and lobeglitazone, are potent selective PPAR $\gamma$ agonists and are very effective at controlling hyperglycemia, angiogenesis, and cardiac fibrosis [36-39]. Agonists of PPARs have arisen with the ability to bind to multiple isoforms, which are known as dual agonists or pan agonists, such as saroglitazar (PPAR $\alpha$ and $\gamma$ dual agonist) [40, 41], elafibranor (also known as GFT505; PPAR $\alpha$ and $\delta$ dual agonist) [42, 43], and IVA337 (agonist of PPAR $\alpha, \beta / \delta$, and $\gamma$ ] [44]. However, most of these agonists were later abandoned because of serious adverse effects $[45,46]$. To solve this problem, a new generation PPAR $\alpha$-specific agonist, pemafibrate, was developed to maximize receptor-mediated effects and diminish side effects [47]. Furthermore, a recent study found that arjunolic acid (assigned as a PPAR $\alpha$ agonist) regresses cardiac fibrosis by inhibiting non-canonical transforming growth factor- $\beta$ signaling [48].

PPARs are gaining interest for the treatment of metabolic and cardiovascular diseases. Accumulating evidence has shown that the three PPAR subtypes function in the cardiovascular system and influence disease development [28, 38, 48-54]. However, the detailed mechanisms of PPARs in cardiovascular remodeling and dysfunction are still elusive. Over the past few decades, PPARs have been investigated extensively as therapeutic targets in cardiovascular diseases $[49,55,56]$. In this field, diverse approaches, such as

\section{KARGER}


Li et al.: PPAR $\alpha$ in Cardiovascular Diseases

transgenic animals with cardiac-restricted overexpression or deletion of PPAR genes or activation of PPARs with specific agonists in various models of cardiac diseases, have been used to define the roles of PPARs in the pathogenesis of cardiac disorders. Experimental studies in animal models of metabolic diseases also revealed that the activation of PPARs protects against vascular complications through anti-inflammatory, anti-atherogenic, and anti-oxidant actions. However, the molecular mechanisms mediating these protective effects are not understood fully.

\section{PPAR $\alpha$ in vascular injury}

In the circulatory system, PPAR $\alpha$ is expressed by endothelial cells, vascular smooth muscle cells (VSMCs) [57], and monocytes/macrophages [58, 59]. Evidence from animal models and clinical studies has demonstrated a link between inflammation and vascular injury, which is a complex cascade of events involving endothelial denudation, the release of growth factors and cytokines, platelet activation, and smooth muscle cell proliferation and migration to the subendothelial space to form neointimal hyperplasia, leading to vascular stenosis [57, $60,61]$. The inflammatory processes characterized by the adhesion of monocytes and the secretion of inflammatory cytokines alter vascular function [61]. PPAR $\alpha$ activation limits the inflammatory response of endothelial cells and VSMCs by inhibiting pro-inflammatory signaling pathways and improving the lipid profile, thus contributing to the anti-atherogenic action of PPAR $\alpha$ agonists [62]. The absence of PPAR $\alpha$ in mice causes a prolonged response to inflammatory stimuli [63]. This anti-inflammatory effect of PPAR $\alpha$ could result from its negative regulation of vascular inflammatory gene expression by interfering with nuclear factor (NF)- $\kappa B$ and activator protein-1 [64, 65]. Moreover, emerging evidence has also demonstrated that the ligand-activated transcription factor PPAR $\alpha$ could act with the histone deacetylase sirtuin 1 (SIRT1) to regulate vascular pathophysiology. For example, Wang et al. reported that the activation of PPAR $\alpha$ by fenofibrate inhibits cell apoptosis in vascular adventitial fibroblasts partly through the SIRT1-mediated deacetylation of Fox01 [66]. In addition to modulating endothelial cell inflammatory processes, PPAR $\alpha$ agonists enhance the expression of endothelial nitric oxide synthase (eNOS) and the release of nitric oxide (NO) $[67,68]$.

In the disease condition, some lipid metabolites such as eicosanoids and polyunsaturated FAs upregulate PPAR $\alpha$ expression to modulate the expression of inflammatory cytokines and the proliferative response in smooth muscle cells [69]. Many contradictory effects have been ascribed to PPAR ligands in vascular and inflammatory cells. When the vasculature is damaged, VSMCs migrate into the intima of the arterial wall, where they subsequently proliferate and synthesize extracellular matrix, resulting in intimal hyperplasia. The activation of smooth muscle cell proliferation is a key event in the development of atherosclerotic complications. In such a case, the proliferative role of PPAR $\alpha$ ligands might promote the entry of VSMCs into a proliferative state in spite of their anti-inflammatory action $[70,71]$. On the contrary, studies from human and mouse primary VSMCs showed that PPAR $\alpha$ can arrest the cell cycle in smooth muscle cells at the G1/S phase, thereby providing a molecular mechanism by which PPAR $\alpha$ interferes directly with cell cycle progression [72, 73]. In vivo evidence demonstrated that $\mathrm{p} 16$ deficiency promotes smooth muscle cell proliferation and intimal hyperplasia, which were markedly enhanced in PPAR $\alpha$-deficient mice. Moreover, treatment with the PPAR $\alpha$ agonist fenofibrate substantially reduces intimal hyperplasia [74]. These findings suggest a potential for PPAR $\alpha$ agonism in preventing vascular restenosis. Further studies are necessary to clarify the discrepancies between these findings. 


\section{PPAR $\alpha$ in heart injury}

Besides the known role of PPAR $\alpha$ in the regulation of energy homeostasis, its involvement in modulating the cellular redox response and inflammation in the heart undergoing ischemia/reperfusion (I/R) injury, hypertrophy, and cardiac fibrosis has been documented in recent reports [48, 75-77]. Bulhak et al. reported that the PPAR $\alpha$ agonist WY-14643 protects the myocardium of type 2 diabetic Goto-Kakizaki rats from I/R injury via the activation of the PI3K/Akt and NO pathway [78]. In addition, dual PPAR $\alpha$ and $\gamma$ agonists might have additive effects on myocardial protection against I/R injury. Qian et al. found that the non-thiazolidinedione dual PPAR $\alpha$ and $\gamma$ agonist aleglitazar protects cardiomyocytes and the heart against I/R injury [79]. Evidence has also shown that PPAR $\alpha$ activation reduces myocardial infarct size and improves postischemic contractile recovery in animal and ex vivo models of I/R [80-82]. Furthermore, this cardioprotective effect was abolished in PPAR $\alpha^{-/}$ mice [83]. However, other studies have reported conflicting results. The cardiac-restricted overexpression of PPAR $\alpha$ leads to impaired cardiac recovery after ischemia [84-86], and the use of the PPAR $\alpha$ agonist WY-14643 during repetitive I/R results in the intramyocardial triglyceride (TG) accumulation, increased generation of reactive oxygen species (ROS), and subsequent enhancement of inflammation, apoptosis, and contractile dysfunction [87]. The detrimental effect of PPAR $\alpha$ may be attributed to the increased production of ROS and lipotoxicity due to a switch of metabolism from glucose to FA utilization [88]. The contradictory results from cardiac-restricted PPAR $\alpha$ overexpression and systemic PPAR $\alpha$ activation in I/R heart models might be due to the effect of non-cardiac cells such as inflammatory cells. Moreover, the non-specific effects of these PPAR $\alpha$ agonists on the heart need to be investigated further.

PPAR $\alpha$ is a potent antagonist of inflammation. The synthetic PPAR $\alpha$ activator fenofibrate prevents the development of hypertension and improves myocardial inflammation and fibrosis in angiotensin II-infused rats [89]. All three PPARs exert an anti-inflammatory

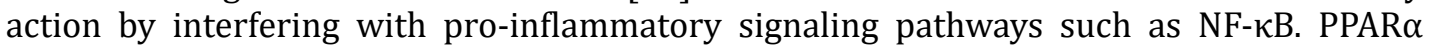
activation inhibits the cardiac expression of transforming necrosis factor- $\alpha$ partly by antagonizing nuclear NF- $\kappa \mathrm{B}$ activity in neonatal rat cardiac myocytes [90]. Moreover, the decreased activation of protein kinases, such as extracellular signal-regulated kinase $1 / 2$, c-Jun N-terminal kinase, Akt, and glycogen synthase kinase 3 beta, may also contribute to the effect of PPAR $\alpha$ on the heart [91-96].

Fibrates are used clinically for the treatment of dyslipidemia. They have been shown to enhance FAO, improve endothelial cell function, and decrease myocardial fibrosis and hypertrophy in animal models of heart failure [97]. Moreover, fenofibrate plus metformin exert a cardio-protective effect in a type 2 diabetes and acute myocardial infarction model [98]. Another PPAR $\alpha$ agonist, AVE8134, has been shown to regress cardiac hypertrophy and fibrosis [99]. As the natural ligands for PPAR $\alpha$, FAs were reported to be defective in hypertrophic cardiomyopathy due to the reduced expression of the FA transporter cluster of differentiation-36 (CD36) [100,101]. Overall, the cardiac response to various agonists of PPAR $\alpha$ might be different because of ligand-dependent variation.

\section{PPAR $\alpha$ in blood pressure regulation}

PPAR $\alpha$ is expressed in both the endothelium and VSMCs $[58,59]$, suggesting that it may have an effect on vascular tone. The reactivity of the arterial wall is controlled in part by biomechanical inputs, including blood flow and blood pressure [10]. As mentioned above, the activation of PPAR $\alpha$ by its ligands is important in the uptake, utilization, and catabolism of FAs through the upregulation of genes involved in FA transport and peroxisomal and mitochondrial FA $\beta$-oxidation. Moreover, PPAR $\alpha$ ligands exert other actions on the vasculature $[102,103]$. 
Blood vessel capacity and vasoconstriction are two important elements in the control of blood pressure. NO plays a significant role in the regulation of vascular tone, platelet aggregation, oxidative stress, leukocyte adherence, and smooth muscle cell mitogenesis [104]. Impairment of the NO/NOS system is one of the most important pathological events in the early phase of the development of hypertension. PPARs have been implicated as transcriptional regulators of the expression and activity of endogenous vasoconstrictors and their receptors. Therefore, it is possible that the induction of PPAR $\alpha$ may attenuate the vasoconstriction response to major endogenous vasoconstrictors such as angiotensin II (Ang II), thromboxane A2 (TXA2), and endothelin 1 (ET-1) [102, 105]. The PPAR $\alpha$ ligand clofibrate reduces high blood pressure and improves vascular reactivity in spontaneously hypertensive rats probably through the increased production of NO [106]. Some results have suggested that in the early stage of aortic coarctation-induced hypertension, stimulation of PPAR $\alpha$ by clofibrate improves hypertension possibly by increasing antioxidant defenses, enhancing eNOS activity, and resetting the renin-angiotensin (RAS) system in the vasculature [105]. Overall, the blood pressure lowering effect of PPAR agonists are cardio-protective and could help to correct vascular structure and endothelial dysfunction in experimental models of hypertension [107].

\section{PPAR $\alpha$ in lipid disorder-related cardiovascular injury}

PPAR $\alpha$ regulates cardiac energy and lipid metabolism and plays a role in mitochondrial FA $\beta$-oxidation, which is critical for fuel generation in the heart through the transcriptional activation of carnitine palmitoyl transferase I [108]. The heart primarily relies on mitochondrial FAO to ensure ATP generation, but has metabolic flexibility to switch to other energy substrates, mainly glucose. This switch in substrate preference is observed in myocardial ischemia, cardiac hypertrophy, and heart failure [109]. The best evidence to support a causal role for metabolic disturbances in the development of cardiac dysfunction is the observation that children with genetic defects in FAO enzymes, which force the heart to rely on glucose, often develop cardiomyopathy [110]. However, PPAR $\alpha$ expression can be downregulated by glucose, which can reduce FAO levels [107].

In addition to their direct anti-inflammatory and anti-atherosclerotic effects on the artery wall, PPAR $\alpha$ and its agonists show a beneficial action on the metabolism of lipids and lipoproteins [111]. PPAR $\alpha$ may alter lipid metabolism through multiple mechanisms that facilitate the transfer of FAs into mitochondria $[108,112]$. Moreover, PPAR $\alpha$ binds to synthetic and natural ligands to reduce the half-life of the PPAR $\alpha$ receptor and finally alters lipid metabolism for the treatment of dyslipidemia, a major risk factor of cardiovascular diseases. Fibrates, which are PPAR $\alpha$ agonists, are prescribed widely to reduce TG levels and raise high-density lipoprotein (HDL) levels with a modest effect on lowering low-density lipoprotein (LDL) levels. In the clinical setting, the recognized synthetic PPAR $\alpha$ ligands for treating hyperlipidemia include clofibrate, ciprofibrate, fenofibrate, and gemfibrozil [113]. Fenofibrate therapy retards the development of atherosclerosis in $\mathrm{ApoE}^{-/-}$and $\mathrm{LDLR}^{-/-}$mice $[114,115]$. Meanwhile, natural ligands, such as LTB4, and FAs, are enriched in tissues with a high capacity for FAO, including the heart, brown adipose tissue, and liver, and to a lesser extent in the kidney and skeletal muscle $[8,116]$. During left ventricular hypertrophy, PPAR $\alpha$ downregulation leads to a decrease of FAO and an increase of lipid accumulation in cardiac myocytes [17]. Moreover, the PPAR $\alpha$ activator LTB4 regulates lipid metabolism and NO production in term placentas of diabetic rats, thereby regulating placental growth [117]. In addition, some novel dual PPAR agonists targeting both PPAR $\alpha$ and PPAR $\gamma$ have beneficial effects on lowering glucose and maintaining lipid homeostasis.

The mechanisms mediating the hypolipidemic effects of PPAR $\alpha$ may include: (1) the regulation of FAO metabolism and reduction of very low-density lipoprotein production; and (2) PPAR $\alpha$ and their ligands reduce the expression of genes governing the intravascular hydrolysis of TG and LDLs, while they increase the expression of genes governing HDL

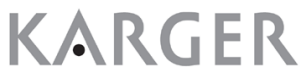


Table 1. PPAR $\alpha$ polymorphisms associated with cardiovascular diseases

\begin{tabular}{lcc}
\hline \multicolumn{1}{c}{ Studies } & Polymorphisms & Associated diseases \\
\hline Lin Y et al. 2012 [127] & PPAR $\alpha$ Leu 162 Val (rs1800206) & Essential Hypertension \\
Arias et al. 2011 [131] & PPAR $\alpha$ Leu 162 Val (rs1800206) & Stage C heart failure \\
Gouni-Berthold I et al. 2004 [132] & PPAR $\alpha$ Leu 162 Val (rs1800206) & Atherosclerotic disease \\
Flavell et al. 2002 [128] & PPAR $\alpha$ intron 7 G>C (rs4253778) & Coronary artery disease \\
Jamshidi et al. 2002 [133] & PPAR $\alpha$ intron 7 G $>$ C (rs4253778) & Left ventricular hypertrophy \\
Reinhard et al. 2008 [135] & PPAR $\alpha$ rs135551/rs135543 & Myocardial infarction \\
Enquobahrie et al. 2008 [125] & PPAR $\alpha$ rs4253623 & Myocardial infarction \\
\hline
\end{tabular}

production. In short, PPAR $\alpha$ upregulates lipoprotein lipase and preserves HDLs $[118,119]$ by remodeling the size and composition of HDLs and facilitating TG metabolism through the increased transfer of unesterified cholesterol to HDLs [120-123].

\section{Association of PPAR $\alpha$ polymorphisms with cardiovascular diseases}

Recently, reports have suggested a close relationship between PPAR $\alpha$ polymorphisms and cardiovascular diseases (Table 1), including rs4253623, rs1800206 (L162V), rs4253778, rs135539, and rs135551 [124-127]. In the Lipid Coronary Angiography Trial, the V162 allele of L162V was associated with the reduced progression of angiographically assessed diffuse atherosclerosis, whereas the prospective Northwick Park Heart Survey found no impact of the L162V variant on the risk of ischemic heart disease [128]. In addition, subjects with the V162 allele are more likely to have high blood pressure [129]. Compared with L162 homozygotes, V162 allele carriers are more likely to develop diabetes mellitus or insulin resistance, but are associated with a reduced risk of cardiovascular events among the population of patients with diabetes mellitus/insulin resistance [130]. Another study found that the V162 allele of the human PPAR $\alpha$ gene was a new risk factor for the development of stage C heart failure, likely via depressed cardiac PPAR $\alpha$ activity [131]. Additionally, some data have suggested that the PPAR $\alpha$ L162V polymorphism might protect against the development of atherosclerosis or coronary heart disease in patients with type 2 diabetes mellitus [132].

rs4253778 G>C is a polymorphism located in intron 7 of PPAR $\alpha$. Carriers of the C allele have significantly increased progression of coronary atherosclerosis compared with $\mathrm{G}$ allele homozygotes [128]. Studies revealed that $78 \%$ of V162 alleles are in combination with the intron $7 \mathrm{C}$ allele, and the atheroprotective V162 allele strongly attenuates the proatherosclerotic effect of the intron 7 Callele [128]. PPAR $\alpha$ intron $7 \mathrm{G} / \mathrm{C}$ was also associated with physiological and pathological left ventricular hypertrophy in 144 young male British Army recruits undergoing a 10-week physical training program and in 1148 men and women participating in the echocardiographic substudy of the Third Monitoring Trends and Determinants in Cardiovascular Disease Augsburg study [133]. In these studies, C allele homozygotes had a significantly greater left ventricular mass index compared with $\mathrm{G}$ allele homozygotes and $C$ allele heterozygotes, which was greater in hypertensive subjects [133]. Moreover, Halder et al. found that the presence of the G allele of rs135542 was associated with higher cardiometabolic risk [134]. Another report found a significant association between rs135551 and myocardial infarction and an association trend between rs135543 and myocardial infarction [135]. The above evidence indicates that polymorphisms of the PPAR $\alpha$ gene may influence the risk of developing cardiovascular diseases. 
Table 2. Roles of PPAR $\alpha$ ligands in cardiovascular diseases

\begin{tabular}{|c|c|c|}
\hline Related diseases & Pathological roles & PPAR $\alpha$ ligands \\
\hline Vascular injury & $\begin{array}{c}\text { Antiinflammation, improving lipid } \\
\text { metabolism, acting with SIRT1, activation } \\
\text { of NO pathway }\end{array}$ & $\begin{array}{l}\text { LTB4, 8S-HETE, DHA, EPA, } \\
\text { epoxyeicosatrienoic acids, and fenofibrate }\end{array}$ \\
\hline Heart injury & $\begin{array}{l}\text { Antiinflammation, activation of PI3K/Akt, } \\
\text { activation of NO pathway }\end{array}$ & $\begin{array}{l}\text { LTB4, 8S-HETE, DHA, EPA, } \\
\text { epoxyeicosatrienoic acids, fenofibrate, WY- } \\
\text { 14643, GW7647, and AVE8134 }\end{array}$ \\
\hline $\mathrm{BP}$ regulation & Vasodilation, activation of NO pathway & $\begin{array}{l}\text { LTB4, 8S-HETE, PEA, fenofibrate, and } \\
\text { clofibrate }\end{array}$ \\
\hline $\begin{array}{l}\text { Lipid disorder-related } \\
\text { cardiovascular injury }\end{array}$ & $\begin{array}{l}\text { Enhancing cardiac FAO, antiinflammation, } \\
\text { improving lipid metabolism }\end{array}$ & LTB4, 8S-HETE, FAs, and fibrates \\
\hline
\end{tabular}

\section{Pharmacogenetic associations of PPAR $\alpha$ with cardiovascular diseases}

PPARs play important roles in many physiological and pathological processes including the modulation of cellular differentiation, metabolism of carbohydrates, lipids, and proteins, and tumorigenesis. All PPARs share the same structure comprising of a ligand-binding domain and a DNA-binding domain. In the clinical setting, PPAR agonists have been used to treat some diseases. PPAR $\alpha$ is activated by fibrate hypolipidemic drugs and PPAR $\gamma$ is activated by insulin sensitizers of TZDs. No marketed drug is yet available for PPAR $\beta / \delta$. The identification of fibrates and TZDs as respective ligands for PPAR $\alpha$ and PPAR $\gamma$ was a groundbreaking finding that sparked notable pharmaceutical interest in PPARs as potential drug targets for the treatment of metabolic syndrome. One important study enrolled 5518 patients and analyzed the effects of combination therapy with fenofibrate and simvastatin; however, there was no beneficial effect of combined treatment with fenofibrate and simvastatin as compared with simvastatin alone in reducing cardiovascular risk in the majority of high-risk patients with type 2 diabetes [136]. Another study found that fibrates may decrease the incidence of combined cardiovascular outcomes according to meta-analysis of six clinical trials [137]. However, side effects associated with the clinical use of these ligands have emerged. In recent years, new and novel PPAR drugs with broad safety margins and therapeutic potential for metabolic syndrome are being developed, including partial, dual, and pan PPAR agonists, PPAR antagonists, and selective PPAR modulators.

\section{Perspectives of PPAR $\alpha$ in research and the clinical setting}

The activation of PPAR $\alpha$ by its agonists exerts a broad spectrum of biological actions in the vasculature and heart by regulating lipid metabolism and energy homeostasis, reducing inflammation, inhibiting oxidative stress and apoptosis, and improving contractile function. Such pleiotropic activity of PPAR $\alpha$ makes it an interesting therapeutic target for the treatment of various pathologies, especially those linked to dyslipidemia and atherosclerosis that are frequently associated with cardiovascular diseases. Numerous studies using animal or specific cell models with genetic and/or pharmacological interventions have contributed to a better understanding of the pleiotropic effects of PPAR $\alpha$ and have highlighted its protective role in the cardiovascular system under diverse pathological settings (Table 2). However, some aspects of the function of PPAR $\alpha$ are still understood poorly and require further exploration via clinical and basic studies.

\section{Acknowledgements}

This work was supported by Grants from the National Natural Science Foundation of China (nos. 81770740, 81670647, 81770690, 81600557, 81600352, 81600532, 81873599, and 81570616), the National Key Research and Development Program (no. 2016YFC0906103), Youth Medical Talents Project of Jiangsu Province Science and Education Qiang Wei Project 


\section{Cellular Physiology Cell Physiol Biochem 2018;51:2760-2775 and Biochemistry Published \begin{tabular}{l|l} 
DOI: 10.1159/000495969 & $\begin{array}{l}\text { C } 2018 \text { The Author(s). Published by S. Karger AG, Basel } \\
\text { www.karger.com/cpb }\end{array}$
\end{tabular}}

Li et al.: PPARa in Cardiovascular Diseases

(no. QNRC2016091), and Project of Nanjing National Commission on Health and Family Planning (no. ZKX16059 and ZKX16057).

\section{Disclosure Statement}

The authors have no conflicts of interest to disclose.

\section{References}

1 Issemann I, Green S: Activation of a member of the steroid hormone receptor superfamily by peroxisome proliferators. Nature 1990;347:645-650.

-2 Kawada T: [Lipid metabolism related nuclear receptor--the structure, function, expression and classification of peroxisome proliferation-activated receptor (PPAR)]. Nihon Rinsho 1998;56:1722-1728.

-3 Gottlicher M, Widmark E, Li Q, Gustafsson JA: Fatty acids activate a chimera of the clofibric acid-activated receptor and the glucocorticoid receptor. Proc Natl Acad Sci U S A 1992;89:4653-4657.

-4 Kliewer SA, Forman BM, Blumberg B, Ong ES, Borgmeyer U, Mangelsdorf DJ, Umesono K, Evans RM: Differential expression and activation of a family of murine peroxisome proliferator-activated receptors. Proc Natl Acad Sci U S A 1994;91:7355-7359.

-5 Greene ME, Blumberg B, McBride OW, Yi HF, Kronquist K, Kwan K, Hsieh L, Greene G, Nimer SD: Isolation of the human peroxisome proliferator activated receptor gamma cDNA: expression in hematopoietic cells and chromosomal mapping. Gene Expr 1995;4:281-299.

6 Sher T, Yi HF, McBride OW, Gonzalez FJ: cDNA cloning, chromosomal mapping, and functional characterization of the human peroxisome proliferator activated receptor. Biochemistry 1993;32:55985604.

7 Lee SS, Pineau T, Drago J, Lee EJ, Owens JW, Kroetz DL, Fernandez-Salguero PM, Westphal H, Gonzalez FJ: Targeted disruption of the alpha isoform of the peroxisome proliferator-activated receptor gene in mice results in abolishment of the pleiotropic effects of peroxisome proliferators. Mol Cell Biol 1995;15:30123022.

-8 Mukherjee R, Jow L, Noonan D, McDonnell DP: Human and rat peroxisome proliferator activated receptors (PPARs) demonstrate similar tissue distribution but different responsiveness to PPAR activators. J Steroid Biochem Mol Biol 1994;51:157-166.

9 Abbott BD: Review of the expression of peroxisome proliferator-activated receptors alpha (PPAR alpha), beta (PPAR beta), and gamma (PPAR gamma) in rodent and human development. Reprod Toxicol 2009;27:246-257.

10 Zandbergen F, Plutzky J: PPARalpha in atherosclerosis and inflammation. Biochim Biophys Acta 2007;1771:972-982.

11 Marx N, Libby P, Plutzky J: Peroxisome proliferator-activated receptors (PPARs) and their role in the vessel wall: possible mediators of cardiovascular risk? J Cardiovasc Risk 2001;8:203-210.

-12 Dreyer C, Krey G, Keller H, Givel F, Helftenbein G, Wahli W: Control of the peroxisomal beta-oxidation pathway by a novel family of nuclear hormone receptors. Cell 1992;68:879-887.

-13 Poulsen L, Siersbaek M, Mandrup S: PPARs: fatty acid sensors controlling metabolism. Semin Cell Dev Biol 2012;23:631-639.

14 Willson TM, Brown PJ, Sternbach DD, Henke BR: The PPARs: from orphan receptors to drug discovery. J Med Chem 2000;43:527-550.

-15 Blanquart C, Mansouri R, Paumelle R, Fruchart JC, Staels B, Glineur C: The protein kinase C signaling pathway regulates a molecular switch between transactivation and transrepression activity of the peroxisome proliferator-activated receptor alpha. Mol Endocrinol 2004;18:1906-1918.

-16 Su CG, Wen X, Bailey ST, Jiang W, Rangwala SM, Keilbaugh SA, Flanigan A, Murthy S, Lazar MA, Wu GD: A novel therapy for colitis utilizing PPAR-gamma ligands to inhibit the epithelial inflammatory response. J Clin Invest 1999;104:383-389.

-17 Barger PM, Brandt JM, Leone TC, Weinheimer CJ, Kelly DP: Deactivation of peroxisome proliferatoractivated receptor-alpha during cardiac hypertrophic growth. J Clin Invest 2000;105:1723-1730. 


\section{Cellular Physiology Cell Physiol Biochem 2018;51:2760-2775

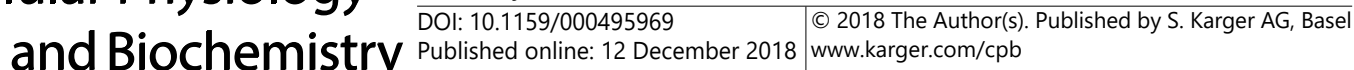

18 Finck BN: The PPAR regulatory system in cardiac physiology and disease. Cardiovasc Res 2007;73:269-277.

19 Lefebvre M, Paulweber B, Fajas L, Woods J, McCrary C, Colombel JF, Najib J, Fruchart JC, Datz C, Vidal $\mathrm{H}$, Desreumaux P, Auwerx J: Peroxisome proliferator-activated receptor gamma is induced during differentiation of colon epithelium cells. J Endocrinol 1999;162:331-340.

-20 Chen W, Wang LL, Liu HY, Long L, Li S: Peroxisome proliferator-activated receptor delta-agonist, GW501516, ameliorates insulin resistance, improves dyslipidaemia in monosodium L-glutamate metabolic syndrome mice. Basic Clin Pharmacol Toxicol 2008;103:240-246.

21 Coll T, Alvarez-Guardia D, Barroso E, Gomez-Foix AM, Palomer X, Laguna JC, Vazquez-Carrera M: Activation of peroxisome proliferator-activated receptor-\{delta\} by GW501516 prevents fatty acid-induced nuclear factor-\{kappa\}B activation and insulin resistance in skeletal muscle cells. Endocrinology 2010;151:15601569.

22 Kota BP, Huang TH, Roufogalis BD: An overview on biological mechanisms of PPARs. Pharmacol Res 2005;51:85-94.

23 Guan Y: Targeting peroxisome proliferator-activated receptors (PPARs) in kidney and urologic disease. Minerva Urol Nefrol 2002;54:65-79.

24 Guan Y, Zhang Y, Schneider A, Davis L, Breyer RM, Breyer MD: Peroxisome proliferator-activated receptorgamma activity is associated with renal microvasculature. Am J Physiol Renal Physiol 2001;281:F10361046.

-25 Cowart LA, Wei S, Hsu MH, Johnson EF, Krishna MU, Falck JR, Capdevila JH: The CYP4A isoforms hydroxylate epoxyeicosatrienoic acids to form high affinity peroxisome proliferator-activated receptor ligands. J Biol Chem 2002;277:35105-35112.

-26 Liss KH, Finck BN: PPARs and nonalcoholic fatty liver disease. Biochimie 2017;136:65-74.

27 Wang S, Hannafon BN, Zhou J, Ding WQ: Clofibrate induces heme oxygenase 1 expression through a PPARalpha-independent mechanism in human cancer cells. Cell Physiol Biochem 2013;32:1255-1264.

-28 Deng Y, Han X, Yao Z, Sun Y, Yu J, Cai J, Ren G, Jiang G, Han F: PPARalpha Agonist Stimulated Angiogenesis by Improving Endothelial Precursor Cell Function Via a NLRP3 Inflammasome Pathway. Cell Physiol Biochem 2017;42:2255-2266.

29 Ji Y, Wang Z, Li Z, Liu J: Modulation of LPS-mediated inflammation by fenofibrate via the TRIF-dependent TLR4 signaling pathway in vascular smooth muscle cells. Cell Physiol Biochem 2010;25:631-640.

30 Shi C, Min L, Yang J, Dai M, Song D, Hua H, Xu G, Gonzalez FJ, Liu A: Peroxisome Proliferator-Activated Receptor alpha Activation Suppresses Cytochrome P450 Induction Potential in Mice Treated with Gemfibrozil. Basic Clin Pharmacol Toxicol 2017;121:169-174.

-31 Saha L, Bhandari S, Bhatia A, Banerjee D, Chakrabarti A: Anti-kindling Effect of Bezafibrate, a Peroxisome Proliferator-activated Receptors Alpha Agonist, in Pentylenetetrazole Induced Kindling Seizure Model. J Epilepsy Res 2014;4:45-54.

-32 Fidaleo M, Sartori C: Administration of ciprofibrate to lactating mothers induces PPARalpha-signaling pathway in the liver and kidney of suckling rats. Exp Toxicol Pathol 2008;60:33-41.

-33 Brown PJ, Smith-Oliver TA, Charifson PS, Tomkinson NC, Fivush AM, Sternbach DD, Wade LE, Orband-Miller L, Parks DJ, Blanchard SG, Kliewer SA, Lehmann JM, Willson TM: Identification of peroxisome proliferatoractivated receptor ligands from a biased chemical library. Chem Biol 1997;4:909-918.

-34 Shureiqi I, Jiang W, Zuo X, Wu Y, Stimmel JB, Leesnitzer LM, Morris JS, Fan HZ, Fischer SM, Lippman SM: The 15-lipoxygenase-1 product 13-S-hydroxyoctadecadienoic acid down-regulates PPAR-delta to induce apoptosis in colorectal cancer cells. Proc Natl Acad Sci U S A 2003;100:9968-9973.

35 Forman BM, Tontonoz P, Chen J, Brun RP, Spiegelman BM, Evans RM: 15-Deoxy-delta 12, 14-prostaglandin $\mathrm{J} 2$ is a ligand for the adipocyte determination factor PPAR gamma. Cell 1995;83:803-812.

-36 Nagy L, Tontonoz P, Alvarez JG, Chen H, Evans RM: Oxidized LDL regulates macrophage gene expression through ligand activation of PPARgamma. Cell 1998;93:229-240.

37 Tontonoz P, Nagy L, Alvarez JG, Thomazy VA, Evans RM: PPARgamma promotes monocyte/macrophage differentiation and uptake of oxidized LDL. Cell 1998;93:241-252.

-38 Sun L, Yuan Q, Xu T, Yao L, Feng J, Ma J, Wang L, Lu C, Wang D: Pioglitazone, a Peroxisome ProliferatorActivated Receptor x03B3; Agonist, Ameliorates Chronic Kidney Disease by Enhancing Antioxidative Capacity and Attenuating Angiogenesis in the Kidney of a 5/6 Nephrectomized Rat Model. Cell Physiol Biochem 2016;38:1831-1840. 


\section{Cellular Physiology Cell Physiol Biochem 2018;51:2760-2775 and Biochemistry \begin{tabular}{l|l} 
DOI: 10.1159/000495969 & (c) 2018 The Author(s). Published by S. Karger AG, Basel \\
www.karger.com/cpb
\end{tabular}

39 Lim S, Lee KS, Lee JE, Park HS, Kim KM, Moon JH, Choi SH, Park KS, Kim YB, Jang HC: Effect of a new PPARgamma agonist, lobeglitazone, on neointimal formation after balloon injury in rats and the development of atherosclerosis. Atherosclerosis 2015;243:107-119.

40 Jain MR, Giri SR, Bhoi B, Trivedi C, Rath A, Rathod R, Ranvir R, Kadam S, Patel H, Swain P, Roy SS, Das N, Karmakar E, Wahli W, Patel PR: Dual PPARalpha/gamma agonist saroglitazar improves liver histopathology and biochemistry in experimental NASH models. Liver Int 2018;38:1084-1094.

41 Agrawal R: The first approved agent in the Glitazar's Class: Saroglitazar. Curr Drug Targets 2014;15:151155.

42 Cariou B, Hanf R, Lambert-Porcheron S, Zair Y, Sauvinet V, Noel B, Flet L, Vidal H, Staels B, Laville M: Dual peroxisome proliferator-activated receptor alpha/delta agonist GFT505 improves hepatic and peripheral insulin sensitivity in abdominally obese subjects. Diabetes Care 2013;36:2923-2930.

43 Cariou B, Zair Y, Staels B, Bruckert E: Effects of the new dual PPAR alpha/delta agonist GFT505 on lipid and glucose homeostasis in abdominally obese patients with combined dyslipidemia or impaired glucose metabolism. Diabetes Care 2011;34:2008-2014.

-44 Wettstein G, Luccarini JM, Poekes L, Faye P, Kupkowski F, Adarbes V, Defrene E, Estivalet C, Gawronski X, Jantzen I, Philippot A, Tessier J, Tuyaa-Boustugue P, Oakley F, Mann DA, Leclercq I, Francque S, Konstantinova I, Broqua P, Junien JL: The new-generation pan-peroxisome proliferator-activated receptor agonist IVA337 protects the liver from metabolic disorders and fibrosis. Hepatol Commun 2017;1:524-537.

-45 Henry RR, Lincoff AM, Mudaliar S, Rabbia M, Chognot C, Herz M: Effect of the dual peroxisome proliferatoractivated receptor-alpha/gamma agonist aleglitazar on risk of cardiovascular disease in patients with type 2 diabetes (SYNCHRONY): a phase II, randomised, dose-ranging study. Lancet 2009;374:126-135.

-46 Hamren B, Ohman KP, Svensson MK, Karlsson MO: Pharmacokinetic-pharmacodynamic assessment of the interrelationships between tesaglitazar exposure and renal function in patients with type 2 diabetes mellitus. J Clin Pharmacol 2012;52:1317-1327.

47 Silva AKS, Peixoto CA: Role of peroxisome proliferator-activated receptors in non-alcoholic fatty liver disease inflammation. Cell Mol Life Sci 2018;75:2951-2961.

48 Bansal T, Chatterjee E, Singh J, Ray A, Kundu B, Thankamani V, Sengupta S, Sarkar S: Arjunolic acid, a peroxisome proliferator-activated receptor alpha agonist, regresses cardiac fibrosis by inhibiting noncanonical TGF-beta signaling. J Biol Chem 2017;292:16440-16462.

49 Abushouk AI, El-Husseny MWA, Bahbah EI, Elmaraezy A, Ali AA, Ashraf A, Abdel-Daim MM: Peroxisome proliferator-activated receptors as therapeutic targets for heart failure. Biomed Pharmacother 2017;95:692-700.

50 Khayat MT, Nayeem MA: The Role of Adenosine A2A Receptor, CYP450s, and PPARs in the Regulation of Vascular Tone. Biomed Res Int 2017;2017:1720920.

51 Wei WY, Zhang N, Li LL, Ma ZG, Xu M, Yuan YP, Deng W, Tang QZ: Pioglitazone Alleviates Cardiac Fibrosis and Inhibits Endothelial to Mesenchymal Transition Induced by Pressure Overload. Cell Physiol Biochem 2018;45:26-36.

-52 Gong K, Chen M, Li R, He Y, Zhu H, Yao D, Oparil S, Zhang Z: Smad3-mSin3A-HDAC1 Complex is Required for TGF-beta1-Induced Transcriptional Inhibition of PPARgamma in Mouse Cardiac Fibroblasts. Cell Physiol Biochem 2016;40:908-920.

53 Xu X, He M, Liu T, Zeng Y, Zhang W: Effect of Salusin-beta on Peroxisome Proliferator-Activated Receptor Gamma Gene Expression in Vascular Smooth Muscle Cells and its Possible Mechanism. Cell Physiol Biochem 2015;36:2466-2479.

54 Qi HP, Wang Y, Zhang QH, Guo J, Li L, Cao YG, Li SZ, Li XL, Shi MM, Xu W, Li BY, Sun HL: Activation of peroxisome proliferator-activated receptor gamma (PPARgamma) through NF-kappaB/Brg1 and TGFbeta1 pathways attenuates cardiac remodeling in pressure-overloaded rat hearts. Cell Physiol Biochem 2015;35:899-912.

55 Bendaya I, Riahi A, Kharat M, Kahla S, Sdiri W, Oueslati R: STAT1 and STAT6 Act as Antagonistic Regulators of PPARgamma in Diabetic Patients with and without Cardiovascular Diseases. Clin Lab 2018;64:287-294.

-56 Araki E, Yamashita S, Arai H, Yokote K, Satoh J, Inoguchi T, Nakamura J, Maegawa H, Yoshioka N, Tanizawa Y, Watada H, Suganami H, Ishibashi S: Effects of Pemafibrate, a Novel Selective PPARalpha Modulator, on Lipid and Glucose Metabolism in Patients With Type 2 Diabetes and Hypertriglyceridemia: A Randomized, Double-Blind, Placebo-Controlled, Phase 3 Trial. Diabetes Care 2018;41:538-546. 


\section{Cellular Physiology Cell Physiol Biochem 2018;51:2760-2775 and Biochemistry \begin{tabular}{l|l} 
DOI: 10.1159/000495969 & (c) 2018 The Author(s). Published by S. Karger AG, Basel \\
www.karger.com/cpb
\end{tabular}

57 Zhao Y, Liu Y, Jing Z, Peng L, Jin P, Lin Y, Zhou Y, Yang L, Ren J, Xie Q, Jin X: N-oleoylethanolamide suppresses intimal hyperplasia after balloon injury in rats through AMPK/PPARalpha pathway. Biochem Biophys Res Commun 2018;496:415-421.

58 Neve BP, Fruchart JC, Staels B: Role of the peroxisome proliferator-activated receptors (PPAR) in atherosclerosis. Biochem Pharmacol 2000;60:1245-1250.

59 Peng Y, Li Q, Zhang L, Bai M, Zhang Z: Peroxisome Proliferator-Activated Receptor alpha Plays an Important Role in the Expression of Monocyte Chemoattractant Protein-1 and Neointimal Hyperplasia after Vascular Injury. PPAR Res 2012;2012:970525.

-60 Koppara T, Cheng Q, Yahagi K, Mori H, Sanchez OD, Feygin J, Wittchow E, Kolodgie FD, Virmani R, Joner M: Thrombogenicity and early vascular healing response in metallic biodegradable polymer-based and fully bioabsorbable drug-eluting stents. Circ Cardiovasc Interv 2015;8:e002427.

-61 Tesfamariam B: Platelet function in intravascular device implant-induced intimal injury. Cardiovasc Revasc Med 2008;9:78-87.

62 Plutzky J: The PPAR-RXR transcriptional complex in the vasculature: energy in the balance. Circ Res 2011;108:1002-1016.

63 Devchand PR, Keller H, Peters JM, Vazquez M, Gonzalez FJ, Wahli W: The PPARalpha-leukotriene B4 pathway to inflammation control. Nature 1996;384:39-43.

64 Delerive P, De Bosscher K, Besnard S, Vanden Berghe W, Peters JM, Gonzalez FJ, Fruchart JC, Tedgui A, Haegeman G, Staels B: Peroxisome proliferator-activated receptor alpha negatively regulates the vascular inflammatory gene response by negative cross-talk with transcription factors NF-kappaB and AP-1. J Biol Chem 1999;274:32048-32054.

65 Bocher V, Chinetti G, Fruchart JC, Staels B: [Role of the peroxisome proliferator-activated receptors (PPARS) in the regulation of lipids and inflammation control]. J Soc Biol 2002;196:47-52.

-66 Wang WR, Liu EQ, Zhang JY, Li YX, Yang XF, He YH, Zhang W, Jing T, Lin R: Activation of PPAR alpha by fenofibrate inhibits apoptosis in vascular adventitial fibroblasts partly through SIRT1-mediated deacetylation of Fox01 Exp Cell Res 2015;338:54-63.

67 Goya K, Sumitani S, Xu X, Kitamura T, Yamamoto H, Kurebayashi S, Saito H, Kouhara H, Kasayama S, Kawase I: Peroxisome proliferator-activated receptor alpha agonists increase nitric oxide synthase expression in vascular endothelial cells. Arterioscler Thromb Vasc Biol 2004;24:658-663.

68 Yakubu MA, Nsaif RH, Oyekan AO: peroxisome proliferator-activated receptor alpha activation-mediated regulation of endothelin-1 production via nitric oxide and protein kinase $C$ signaling pathways in piglet cerebral microvascular endothelial cell culture. J Pharmacol Exp Ther 2007;320:774-781.

69 Delerive P, Fruchart JC, Staels B: Peroxisome proliferator-activated receptors in inflammation control. J Endocrinol 2001;169:453-459.

70 Forman BM, Chen J, Evans RM: Hypolipidemic drugs, polyunsaturated fatty acids, and eicosanoids are ligands for peroxisome proliferator-activated receptors alpha and delta. Proc Natl Acad Sci U S A 1997;94:4312-4317.

71 Ng VY, Morisseau C, Falck JR, Hammock BD, Kroetz DL: Inhibition of smooth muscle proliferation by ureabased alkanoic acids via peroxisome proliferator-activated receptor alpha-dependent repression of cyclin D1 Arterioscler Thromb Vasc Biol 2006;26:2462-2468.

-72 Gizard F, Nomiyama T, Zhao Y, Findeisen HM, Heywood EB, Jones KL, Staels B, Bruemmer D: The PPARalpha/p16INK4a pathway inhibits vascular smooth muscle cell proliferation by repressing cell cycledependent telomerase activation. Circ Res 2008;103:1155-1163.

73 Ii M, Hoshiga M, Negoro N, Fukui R, Nakakoji T, Kohbayashi E, Shibata N, Furutama D, Ishihara T, Hanafusa T, Losordo DW, Ohsawa N: Adrenal androgen dehydroepiandrosterone sulfate inhibits vascular remodeling following arterial injury. Atherosclerosis 2009;206:77-85.

74 Gizard F, Amant C, Barbier O, Bellosta S, Robillard R, Percevault F, Sevestre H, Krimpenfort P, Corsini A, Rochette J, Glineur C, Fruchart JC, Torpier G, Staels B: PPAR alpha inhibits vascular smooth muscle cell proliferation underlying intimal hyperplasia by inducing the tumor suppressor p16INK4a. J Clin Invest 2005;115:3228-3238.

75 Yuan J, Mo H, Luo J, Zhao S, Liang S, Jiang Y, Zhang M: PPARalpha activation alleviates damage to the cytoskeleton during acute myocardial ischemia/reperfusion in rats. Mol Med Rep 2018;17:7218-7226.

-76 Mitra A, Datta R, Rana S, Sarkar S: Modulation of NFKB1/p50 by ROS leads to impaired ATP production during MI compared to cardiac hypertrophy. J Cell Biochem 2018;119:1575-1590. 


\section{Cellular Physiology Cell Physiol Biochem 2018;51:2760-2775 \begin{tabular}{l|l|l} 
and Biochemistry 2018 The Author(s). Published by S. Karger AG, Basel \\
Dul 10.1159/000495969
\end{tabular}

77 Chuppa S, Liang M, Liu P, Liu Y, Casati MC, Cowley AW, Patullo L, Kriegel AJ: MicroRNA-21 regulates peroxisome proliferator-activated receptor alpha, a molecular mechanism of cardiac pathology in Cardiorenal Syndrome Type 4. Kidney Int 2018;93:375-389.

78 Bulhak AA, Jung C, Ostenson CG, Lundberg JO, Sjoquist PO, Pernow J: PPAR-alpha activation protects the type 2 diabetic myocardium against ischemia-reperfusion injury: involvement of the PI3-Kinase/Akt and NO pathway. Am J Physiol Heart Circ Physiol 2009;296:H719-727.

-79 Qian J, Chen H, Birnbaum Y, Nanhwan MK, Bajaj M, Ye Y: Aleglitazar, a Balanced Dual PPARalpha and -gamma Agonist, Protects the Heart Against Ischemia-Reperfusion Injury. Cardiovasc Drugs Ther 2016;10.1007/s10557-016-6650-9.

-80 Barlaka E, Ledvenyiova V, Galatou E, Ferko M, Carnicka S, Ravingerova T, Lazou A: Delayed cardioprotective effects of WY-14643 are associated with inhibition of MMP-2 and modulation of Bcl-2 family proteins through PPAR-alpha activation in rat hearts subjected to global ischaemia-reperfusion. Can J Physiol Pharmacol 2013;91:608-616.

81 Bulhak AA, Sjoquist PO, Xu CB, Edvinsson L, Pernow J: Protection against myocardial ischaemia/ reperfusion injury by PPAR-alpha activation is related to production of nitric oxide and endothelin-1 Basic Res Cardiol 2006;101:244-252.

-82 Tian Q, Grzemski FA, Panagiotopoulos S, Ahokas JT: Peroxisome proliferator-activated receptor alpha agonist, clofibrate, has profound influence on myocardial fatty acid composition. Chem Biol Interact 2006;160:241-251.

83 Yue TL, Bao W, Jucker BM, Gu JL, Romanic AM, Brown PJ, Cui J, Thudium DT, Boyce R, Burns-Kurtis CL, Mirabile RC, Aravindhan K, Ohlstein EH: Activation of peroxisome proliferator-activated receptor-alpha protects the heart from ischemia/reperfusion injury. Circulation 2003;108:2393-2399.

84 Finck BN, Lehman JJ, Leone TC, Welch MJ, Bennett MJ, Kovacs A, Han X, Gross RW, Kozak R, Lopaschuk GD, Kelly DP: The cardiac phenotype induced by PPARalpha overexpression mimics that caused by diabetes mellitus. J Clin Invest 2002;109:121-130.

85 Sambandam N, Morabito D, Wagg C, Finck BN, Kelly DP, Lopaschuk GD: Chronic activation of PPARalpha is detrimental to cardiac recovery after ischemia. Am J Physiol Heart Circ Physiol 2006;290:H87-95.

-86 Duerr GD, Heinemann JC, Arnoldi V, Feisst A, Kley J, Ghanem A, Welz A, Dewald O: Cardiomyocyte specific peroxisome proliferator-activated receptor-alpha overexpression leads to irreversible damage in ischemic murine heart. Life Sci 2014;102:88-97.

87 Dewald O, Sharma S, Adrogue J, Salazar R, Duerr GD, Crapo JD, Entman ML, Taegtmeyer H: Downregulation of peroxisome proliferator-activated receptor-alpha gene expression in a mouse model of ischemic cardiomyopathy is dependent on reactive oxygen species and prevents lipotoxicity. Circulation 2005;112:407-415.

88 Barlaka E, Galatou E, Mellidis K, Ravingerova T, Lazou A: Role of Pleiotropic Properties of Peroxisome Proliferator-Activated Receptors in the Heart: Focus on the Nonmetabolic Effects in Cardiac Protection. Cardiovasc Ther 2016;34:37-48.

-89 Diep QN, Amiri F, Benkirane K, Paradis P, Schiffrin EL: Long-term effects of the PPAR gamma activator pioglitazone on cardiac inflammation in stroke-prone spontaneously hypertensive rats. Can J Physiol Pharmacol 2004;82:976-985.

-90 Takano H, Nagai T, Asakawa M, Toyozaki T, Oka T, Komuro I, Saito T, Masuda Y: Peroxisome proliferatoractivated receptor activators inhibit lipopolysaccharide-induced tumor necrosis factor-alpha expression in neonatal rat cardiac myocytes. Circ Res 2000;87:596-602.

-91 Huang Q Huang J, Zeng Z, Luo J, Liu P, Chen S, Liu B, Pan X, Zang L, Zhou S: Effects of ERK1/2/PPARalpha/ SCAD signal pathways on cardiomyocyte hypertrophy induced by insulin-like growth factor 1 and phenylephrine. Life Sci 2015;124:41-49.

92 Meng R, Pei Z, Zhang A, Zhou Y, Cai X, Chen B, Liu G, Mai W, Wei J, Dong Y: AMPK activation enhances PPARalpha activity to inhibit cardiac hypertrophy via ERK1/2 MAPK signaling pathway. Arch Biochem Biophys 2011;511:1-7.

93 Drosatos K, Drosatos-Tampakaki Z, Khan R, Homma S, Schulze PC, Zannis VI, Goldberg IJ: Inhibition of c-Jun-N-terminal kinase increases cardiac peroxisome proliferator-activated receptor alpha expression and fatty acid oxidation and prevents lipopolysaccharide-induced heart dysfunction. J Biol Chem 2011;286:36331-36339. 


\section{Cellular Physiology Cell Physiol Biochem 2018;51:2760-2775

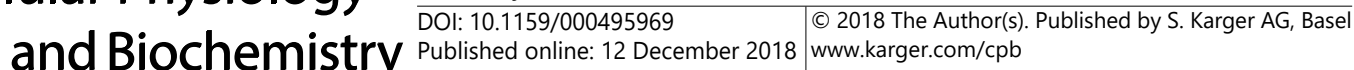

$\$ 94$ Irukayama-Tomobe Y, Miyauchi T, Sakai S, Kasuya Y, Ogata T, Takanashi M, Iemitsu M, Sudo T, Goto $\mathrm{K}$, Yamaguchi I: Endothelin-1-induced cardiac hypertrophy is inhibited by activation of peroxisome proliferator-activated receptor-alpha partly via blockade of c-Jun NH2-terminal kinase pathway. Circulation 2004;109:904-910.

-95 Wu Y, Wang BX, Guo YY, Wang YQ: [The effect of relgulation of PPAR-alpha on cardiac hypertrophy and the relationship between the effect of PPAR-alpha with PI3K/Akt/mTOR pathway]. Zhongguo Ying Yong Sheng Li Xue Za Zhi 2015;31:284-288.

-96 Li R, Zheng W, Pi R, Gao J, Zhang H, Wang P, Le K, Liu P: Activation of peroxisome proliferator-activated receptor-alpha prevents glycogen synthase 3beta phosphorylation and inhibits cardiac hypertrophy. FEBS Lett 2007;581:3311-3316.

-97 Sarma S, Ardehali H, Gheorghiade M: Enhancing the metabolic substrate: PPAR-alpha agonists in heart failure. Heart Fail Rev 2012;17:35-43.

-98 Oidor-Chan VH, Hong E, Perez-Severiano F, Montes S, Torres-Narvaez JC, Del Valle-Mondragon L, PastelinHernandez G, Sanchez-Mendoza A: Fenofibrate plus Metformin Produces Cardioprotection in a Type 2 Diabetes and Acute Myocardial Infarction Model. PPAR Res 2016;2016:8237264.

\$9 Linz W, Wohlfart P, Baader M, Breitschopf K, Falk E, Schafer HL, Gerl M, Kramer W, Rutten H: The peroxisome proliferator-activated receptor-alpha (PPAR-alpha) agonist, AVE8134, attenuates the progression of heart failure and increases survival in rats. Acta Pharmacol Sin 2009;30:935-946.

-100 Lauzier B, Merlen C, Vaillant F, McDuff J, Bouchard B, Beguin PC, Dolinsky VW, Foisy S, Villeneuve LR, Labarthe F, Dyck JR, Allen BG, Charron G, Des Rosiers C: Post-translational modifications, a key process in CD36 function: lessons from the spontaneously hypertensive rat heart. J Mol Cell Cardiol 2011;51:99-108.

101 Tanaka T, Sohmiya K, Kawamura K: Is CD36 deficiency an etiology of hereditary hypertrophic cardiomyopathy? J Mol Cell Cardiol 1997;29:121-127.

102 Newaz M, Blanton A, Fidelis P, Oyekan A: NAD(P)H oxidase/nitric oxide interactions in peroxisome proliferator activated receptor (PPAR)alpha-mediated cardiovascular effects. Mutat Res 2005;579:163-171.

-103 Newaz M, Ranganna K, Truong LD, Oyekan A: Effect of peroxisome proliferator-activated receptor-alpha siRNA on hypertension and renal injury in the rat following nitric oxide withdrawal and high salt diet. J Hypertens 2009;27:2223-2231.

104 Cooke JP, Dzau VJ: Nitric oxide synthase: role in the genesis of vascular disease. Annu Rev Med 1997;48:489-509.

105 Ibarra-Lara L, Cervantes-Perez LG, Perez-Severiano F, Del Valle L, Rubio-Ruiz E, Soria-Castro E, PastelinHernandez GS, Sanchez-Aguilar M, Martinez-Lazcano JC, Sanchez-Mendoza A: PPARalpha stimulation exerts a blood pressure lowering effect through different mechanisms in a time-dependent manner. Eur J Pharmacol 2010;627:185-193.

-106 Yousefipour Z, Newaz M: PPARalpha ligand clofibrate ameliorates blood pressure and vascular reactivity in spontaneously hypertensive rats. Acta Pharmacol Sin 2014;35:476-482.

$\$ 107$ Touyz RM, Schiffrin EL: Peroxisome proliferator-activated receptors in vascular biology-molecular mechanisms and clinical implications. Vascul Pharmacol 2006;45:19-28.

108 Brandt JM, Djouadi F, Kelly DP: Fatty acids activate transcription of the muscle carnitine palmitoyltransferase I gene in cardiac myocytes via the peroxisome proliferator-activated receptor alpha. J Biol Chem 1998;273:23786-23792.

109 Lopaschuk GD, Ussher JR, Folmes CD, Jaswal JS, Stanley WC: Myocardial fatty acid metabolism in health and disease. Physiol Rev 2010;90:207-258.

110 Kelly DP, Strauss AW: Inherited cardiomyopathies. N Engl J Med 1994;330:913-919.

111 Israelian-Konaraki Z, Reaven PD: Peroxisome proliferator-activated receptor-alpha and atherosclerosis: from basic mechanisms to clinical implications. Cardiology 2005;103:1-9.

112 Cheng L, Ding G, Qin Q Huang Y, Lewis W, He N, Evans RM, Schneider MD, Brako FA, Xiao Y, Chen YE, Yang Q: Cardiomyocyte-restricted peroxisome proliferator-activated receptor-delta deletion perturbs myocardial fatty acid oxidation and leads to cardiomyopathy. Nat Med 2004;10:1245-1250.

113 Remick J, Weintraub H, Setton R, Offenbacher J, Fisher E, Schwartzbard A: Fibrate therapy: an update. Cardiol Rev 2008;16:129-141.

114 Duez H, Chao YS, Hernandez M, Torpier G, Poulain P, Mundt S, Mallat Z, Teissier E, Burton CA, Tedgui A, Fruchart JC, Fievet C, Wright SD, Staels B: Reduction of atherosclerosis by the peroxisome proliferatoractivated receptor alpha agonist fenofibrate in mice. J Biol Chem 2002;277:48051-48057. 


\section{Cellular Physiology Cell Physiol Biochem 2018;51:2760-2775

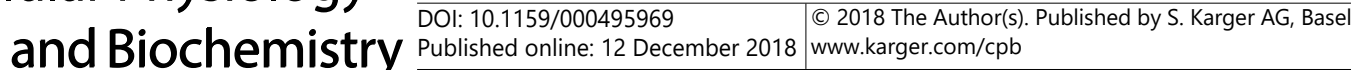

Li et al.: PPARa in Cardiovascular Diseases

115 Srivastava RA, Jahagirdar R, Azhar S, Sharma S, Bisgaier CL: Peroxisome proliferator-activated receptoralpha selective ligand reduces adiposity, improves insulin sensitivity and inhibits atherosclerosis in LDL receptor-deficient mice. Mol Cell Biochem 2006;285:35-50.

116 Braissant O, Foufelle F, Scotto C, Dauca M, Wahli W: Differential expression of peroxisome proliferatoractivated receptors (PPARs): tissue distribution of PPAR-alpha, -beta, and -gamma in the adult rat. Endocrinology 1996;137:354-366.

117 Martinez N, Kurtz M, Capobianco E, Higa R, White V, Jawerbaum A: PPARalpha agonists regulate lipid metabolism and nitric oxide production and prevent placental overgrowth in term placentas from diabetic rats. J Mol Endocrinol 2011;47:1-12.

118 Lee CH, Kang K, Mehl IR, Nofsinger R, Alaynick WA, Chong LW, Rosenfeld JM, Evans RM: Peroxisome proliferator-activated receptor delta promotes very low-density lipoprotein-derived fatty acid catabolism in the macrophage. Proc Natl Acad Sci U S A 2006;103:2434-2439.

119 Lee CH, Olson P, Hevener A, Mehl I, Chong LW, Olefsky JM, Gonzalez FJ, Ham J, Kang H, Peters JM, Evans RM: PPARdelta regulates glucose metabolism and insulin sensitivity. Proc Natl Acad Sci U S A 2006;103:34443449.

120 Gervois P, Torra IP, Fruchart JC, Staels B: Regulation of lipid and lipoprotein metabolism by PPAR activators. Clin Chem Lab Med 2000;38:3-11.

121 Lie J, Lankhuizen IM, Gross B, van Gent T, van Haperen R, Scheek L, Staels B, de Crom R, van Tol A: Fenofibrate reverses the decline in HDL cholesterol in mice overexpressing human phospholipid transfer protein. Biochim Biophys Acta 2005;1738:48-53.

122 Schmitz G, Langmann T: Transcriptional regulatory networks in lipid metabolism control ABCA1 expression. Biochim Biophys Acta 2005;1735:1-19.

123 Panzenboeck U, Kratzer I, Sovic A, Wintersperger A, Bernhart E, Hammer A, Malle E, Sattler W: Regulatory effects of synthetic liver $\mathrm{X}$ receptor- and peroxisome-proliferator activated receptor agonists on sterol transport pathways in polarized cerebrovascular endothelial cells. Int J Biochem Cell Biol 2006;38:13141329.

124 Enquobahrie DA, Smith NL, Bis JC, Carty CL, Rice KM, Lumley T, Hindorff LA, Lemaitre RN, Williams MA, Siscovick DS, Heckbert SR, Psaty BM: Cholesterol ester transfer protein, interleukin-8, peroxisome proliferator activator receptor alpha, and Toll-like receptor 4 genetic variations and risk of incident nonfatal myocardial infarction and ischemic stroke. Am J Cardiol 2008;101:1683-1688.

125 Bouchard-Mercier A, Godin G, Lamarche B, Perusse L, Vohl MC: Effects of peroxisome proliferator-activated receptors, dietary fat intakes and gene-diet interactions on peak particle diameters of low-density lipoproteins. J Nutrigenet Nutrigenomics 2011;4:36-48.

126 Xie HJ, Hai B, Wu M, Chen Q Liu MM, Dong C, Guo ZR: Analysis on the association between PPARalpha/ gamma polymorphisms and lipoprotein(a) in a Chinese Han population. Mol Genet Genomics 2014;289:981-987.

127 Lin Y, Gu SJ, Wu M, Chen Q Zhou ZY, Yu H, Zhang LJ, Luo WS, Guo ZR: [Association between peroxisome proliferator-activated receptors gene polymorphism and essential hypertension]. Zhonghua Liu Xing Bing Xue Za Zhi 2012;33:597-601.

-128 Flavell DM, Jamshidi Y, Hawe E, Pineda Torra I, Taskinen MR, Frick MH, Nieminen MS, Kesaniemi YA, Pasternack A, Staels B, Miller G, Humphries SE, Talmud PJ, Syvanne M: Peroxisome proliferator-activated receptor alpha gene variants influence progression of coronary atherosclerosis and risk of coronary artery disease. Circulation 2002;105:1440-1445.

129 Gu SJ, Guo ZR, Wu M, Ding Y, Luo WS: Association of peroxisome proliferator-activated receptor gamma polymorphisms and haplotypes with essential hypertension. Genet Test Mol Biomarkers 2013;17:418-423.

130 Tai ES, Collins D, Robins SJ, O’Connor JJ, Jr., Bloomfield HE, Ordovas JM, Schaefer EJ, Brousseau ME: The L162V polymorphism at the peroxisome proliferator activated receptor alpha locus modulates the risk of cardiovascular events associated with insulin resistance and diabetes mellitus: the Veterans Affairs HDL Intervention Trial (VA-HIT). Atherosclerosis 2006;187:153-160.

131 Arias T, Beaumont J, Lopez B, Zalba G, Beloqui O, Barba J, Valencia F, Gomez-Doblas JJ, De Teresa E, Diez J: Association of the peroxisome proliferator-activated receptor alpha gene L162V polymorphism with stage C heart failure. J Hypertens 2011;29:876-883. 


\section{Cellular Physiology Cell Physiol Biochem 2018;51:2760-2775 \begin{tabular}{ll|l} 
and Biochemistry & $\begin{array}{l}\text { DOl: 10.1159/000495969 } \\
\text { Published onlIne: } 12 \text { December } 2018\end{array}$ & $\begin{array}{l}\text { () } 2018 \text { The Author(s). Published by S. Karger AG, Basel } \\
\text { wwr.com/cpb }\end{array}$ \\
\hline
\end{tabular} \\ Li et al.: PPARa in Cardiovascular Diseases}

132 Gouni-Berthold I, Giannakidou E, Muller-Wieland D, Faust M, Kotzka J, Berthold HK, Krone W: Association between the PPARalpha L162V polymorphism, plasma lipoprotein levels, and atherosclerotic disease in patients with diabetes mellitus type 2 and in nondiabetic controls. Am Heart J 2004;147:1117-1124.

133 Jamshidi Y, Montgomery HE, Hense HW, Myerson SG, Torra IP, Staels B, World MJ, Doering A, Erdmann J, Hengstenberg C, Humphries SE, Schunkert H, Flavell DM: Peroxisome proliferator--activated receptor alpha gene regulates left ventricular growth in response to exercise and hypertension. Circulation 2002;105:950955.

134 Halder I, Champlin J, Sheu L, Goodpaster BH, Manuck SB, Ferrell RE, Muldoon MF: PPARalpha gene polymorphisms modulate the association between physical activity and cardiometabolic risk. Nutr Metab Cardiovasc Dis 2014;24:799-805.

-135 Reinhard W, Stark K, Sedlacek K, Fischer M, Baessler A, Neureuther K, Weber S, Kaess B, Wiedmann S, Mitsching S, Lieb W, Erdmann J, Meisinger C, Doering A, Tolle R, Jeron A, Riegger G, Hengstenberg C: Association between PPARalpha gene polymorphisms and myocardial infarction. Clin Sci (Lond) 2008;115:301-308.

136 Group AS, Ginsberg HN, Elam MB, Lovato LC, Crouse JR, 3rd, Leiter LA, Linz P, Friedewald WT, Buse JB, Gerstein HC, Probstfield J, Grimm RH, Ismail-Beigi F, Bigger JT, Goff DC, Jr., Cushman WC, SimonsMorton DG, Byington RP: Effects of combination lipid therapy in type 2 diabetes mellitus. N Engl J Med 2010;362:1563-1574.

137 Jakob T, Nordmann AJ, Schandelmaier S, Ferreira-Gonzalez I, Briel M: Fibrates for primary prevention of cardiovascular disease events. Cochrane Database Syst Rev 2016;11:CD009753. 